\title{
OCCURRENCE OF PHYSIOLOGICAL DISEASE IN FLOODED RICE FIELDS
}

\author{
OCORRÊNCIA DE BICO DE PAPAGAIO EM ARROZ IRRIGADO
}

\author{
Ademar Brancher $^{1}$ Flávio Anastácio de Oliveira Camargo ${ }^{2}$ Gabriel de Araújo Santos ${ }^{3}$
}

\section{- SHORT NOTE -}

SUMMARY

The aim of this report is to describe the occurrence of the physiological disease "Parrot beak" in flooded rice grown in Rio de Janeiro state soils. The symptoms occurred particularly in the presence of decomposing organic material, affecting the yield because of the high percentage of sterile spickelets.

Key words: anaerobic decomposition, rice straw, sterility, fitotoxic.

\section{RESUMO}

O objetivo deste trabalho é relatar a ocorrência da doença fisiológica Bico de Papagaio em arroz irrigado cultivado em solos do Estado do Rio de Janeiro. Os sintomas manifestaramse significativamente na presença de material orgânico em decomposição afetando o rendimento de arroz, dada a elevada percentagem de espiguetas estéreis.

Palavras-chave: decomposição anaeróbia, palha de arroz, esterilidade, fitotoxidez.

The incorporation of agricultural residues in the soil before a planting season, has the potential disadvantage that toxic products from the decomposition of incorporated organic material may present negative effects, reducing the germination and the establishment of the seedlings (SCOTT RUSSELL, 1977). More drastic effects have been noted in studies on the decomposition of organic material in flooded soils. Under anaerobic conditions, the problem is increased because of the low microbial metabolic rate of conversion of the added carbon, causing an accumulation of compounds which irreversibly affect final productivity, especially of rice (GOMES et al., 1985).

The combined effects of nutrient immobilization, reduced forms of inorganic $\left(\mathrm{Fe}^{2+}\right.$, $\mathrm{Mn}^{2-}$, etc) and production of metabolites can lead to the induction of physiological diseases in rice cultures (BABA et al., 1964). The aim of this report is to describe the occurrence of the physiological disease "Parrot beak" in flooded rice grown in soils of the state of Rio de Janeiro.

The experiment was carried out in a greenhouse in the Soils Department of UFRRJ, using samples of horizons $\mathrm{A}$ and $\mathrm{Cg}$ of a low humic gley soil

\footnotetext{
Agronomist, MSc., Researcher, Extação Experimental de Urussanga, EPAGRI, Rod. SC 446, Km 16, Caixa Postal 49, 88840-000Urussanga, SC.

Graduate Student, Curso de Doutorado em Ciência do Solo, Departamento de Solos, Faculdade de Agronomia, Universidade Federal do Rio Grande do Sul (UFRGS), Caixa Postal 776, 90001-970 - Porto Alegre, RS. Corresponding author.

"Agronomist, MSc., PhD, Professor of the Departamento de Solos, Instituto de Agronomia, Universidade Federal Rural do Rio de Janeiro. Km 47. Antiga Rodovia Rio - São Paulo, 23851-970 - Seropédica, RJ. 
collected from the São João river Valley, Casemiro de Abreu (RJ). The treatments used were the two horizons in the presence or absence of cow manure or rice straw, both added at the rate of $56 \mathrm{ton} / \mathrm{ha}$, and NPK and lime as recommended. Various combinations of these treatments were used. At the end of the experimental period, the percentage of sterile spikelets were determined and a visual estimate made of the results according to the scoring method proposed by IRRI (1980) for numerical analysis of physiological disease (0-3 normal; 4-5 with sligt symptoms and 6-9 strongly affected). Morphologically, this disease is described by the spickelets that take on the appearance of parrot's beak, with the lemma giowing more than the palea and curving over it. The symptoms are also seen in the rhizosphere. Which becomes thickened, with few root hairs, and the plants tend to put out occasional new tillers on the lower nodes, which are poorly developed. The occurrence of this disease berore the panicles emergency can inhibit the production of grains or cause irregular forms.

The occurrence of this physiological disease was more pronunced in the presence of incorporated rice straw. The principal symptom was up to $100 \%$ sterile spickelets when no mineral fertilizer was added. Manure alone diminished the incidence of the disease in surface horizon A. The symptoms atenuation in this horizon were probably due to the higher level of $\mathrm{N}$ in this horizon, altough the addition of $\mathrm{N}$ and $\mathrm{P}$ in the manure could possibly have increased the activity of methanogenic bacteria, responsible for the degradation, of phytotoxins to methane which is associated with anaerobic decomposition of organic material (CHANDRASEKARAN \& YOSHIDA, 19973).

Using the scale of symptom severity (IRRI, 1980), it was possible to describe the stages of the disease numerically by visual analysis of the rice plants. Simple linear correlation of these values obtained for percent sterility gave a coefficient of $0.961(p<0.001)$. This coefficient indicates a direct relationship, showing that the disease was almost totally responsible for the high percentage of sterile spickelets noted in the present report (Figure 1).

This disease was described to be the result of nutritional stress caused by excess of undecomposed organic material in poorly drained soils (PEDROSO, 1985). BABA et al. (1964) noted the occurrence of a similar disease in Japan; that is, an extreme sterility of the flowers, called "Hideriaodachi", and with a similar deformation of the spickelets. Similar symptoms and management are also described for the physiological disease straighthead (BABA et al., 1964).

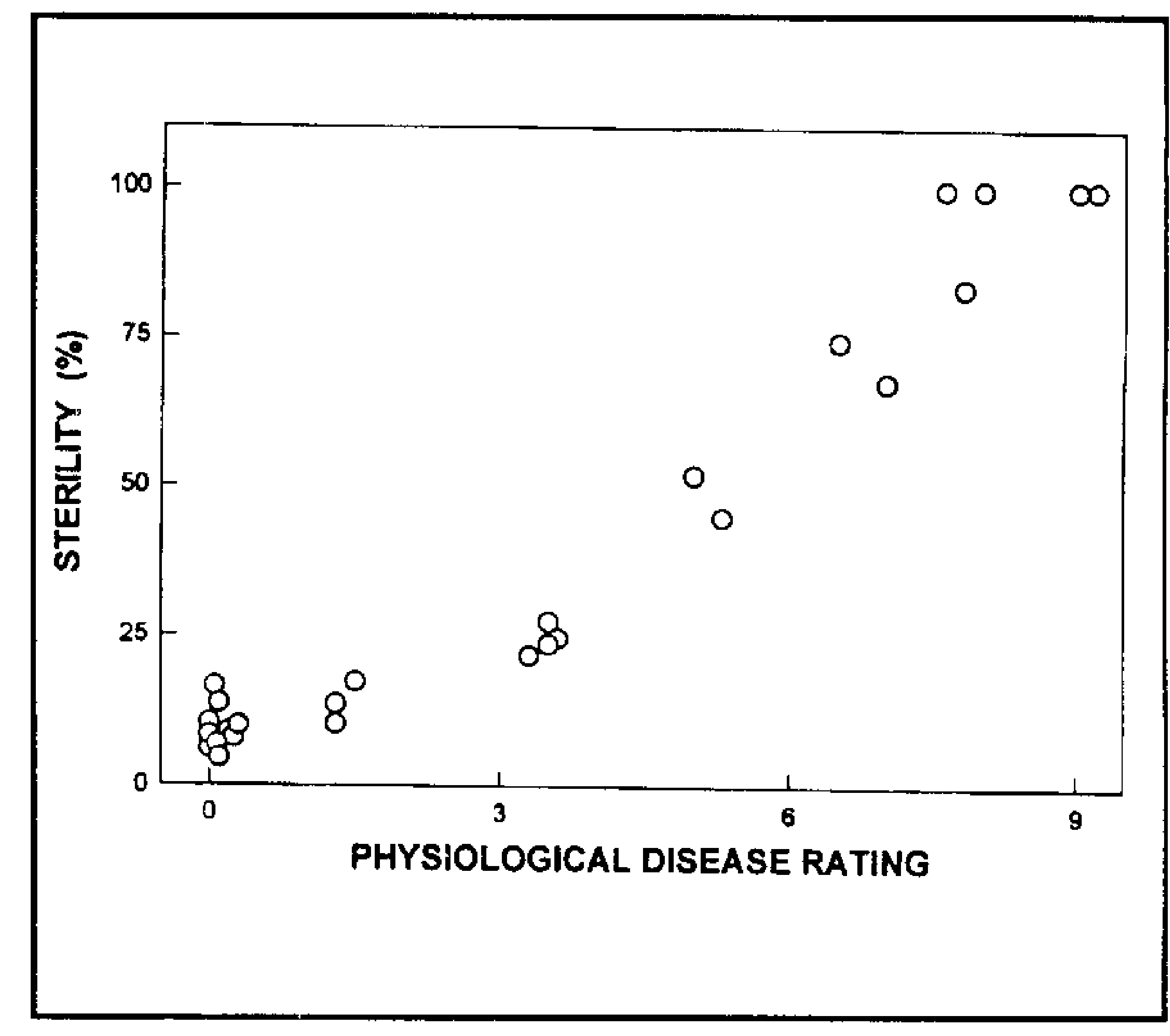

Figure 1. Relationship between percentage of serile spickelets and visual rating of the physiological disease using the scale proposed by IRRI (1980). 0-3 = normal; $4-5=$ slight symptoms and 6-9 = strongly affected.

Straighthead is a symptom of a physiological condition that may be due to one of several causes. Under various names it occurs in many countries, and sometimes causes extensive damage. In these disease, the panicles of affected plants remain upright at maturity because of high (or complete) sterility and as a consequence of their very light weight. The hulls, the paleas or lemmas or both, are distorted, beak-shaped, reduced or may be lacking. The pistil of affected flowers are generally absent. In severe cases, the entire panicles are reduced in size and emerge slowly or incompletely from the bootleaf. The affected plants sometimes remain in the vegetative phase, are dark green, and produce tillers at the lower nodes (OU, 1972) like in this report. Straihthead is often severe in slightly sand clay soils which are not drained completely. The exact cause is un known, but it is believed that the disorder may be due to unfavorable soil conditions aggravated by prolonged flooding.

These effects could result from lesions in the meristematic tissue of the radicles (CHOU \& PATRICK, 1976), which would result in inhibition of cell division. On the other hand, the phytotoxins produced in this system are strong inhibitors of mitochondrial functions, including decopling of oxidative phosphorilation, inhibition of transport of metabolites and glycoytic enzimes dissolved in the cytosol and associated with endomembranes such as those responsible for polisaccharide synthesis and ATPase (WOJTCZAK, 1976). 
In general, these diseases occur in poorly drained soils with a long period of stagnant water followed by drying. They never occur without the drying period and the symptoms are related to soils with a high content of readily degradable organic matter. Apparently, this disease can be avoided by the water management during the cultivation cycle, maintaining the material under anaerobic incubation for periods longer than 30 days (RAO \& MIKKELSEN, 1976).

\section{REFERENCES}

BABA, I., INADA, K., TAKIJIMA, K. Mineral nutrition and the occurrence of physiological diseases. In: IRRI. The mineral nutrition of rice plant. Baltimore: The John Hopkins Press, 1964. Cap. 12. p.173-195.

CHANDRASEKARAN, S., YOSHIDA, T. Effect of organic acid transformation in submerged soil on the growth of the rice plant. Soil Science and Plant Nutrition, Tokyo, v.19, p.39-45, 1973.

CHOU, C.H., PATRICK, Z.A. Identification and phytotoxic activity of compounds produced during decomposition of corn and rye residues in soil. Journal of Chemistry and Ecology, New York, v.2, p.369-387, 1976.

GOMES, A.S., VAHL, L.C., PAULETTO, E.A., et al. Manejo de água em arroz irrigado. In: EMBRAPA. Fundamentos para a cultura do arroz irrigado. Fundação Cargill, Campinas, 1985. p.251-276.

IRRI-INTERNATIONAL RICE RESEARCH INSTITUTE. International rice testing program. In: Standart evaluacion system for rice. 2 ed. Los Bănos, 1980. 94 p.

OU, S.H. Rice disease. London: The Eastern Press, 1972. Part VIII: Physiological disease: p.356-359.

PEDROSO, B.A. Arroz irrigado. Obtenção e manejo de cultivares. 2. ed. Porto Alegre: Sagra, 1985. $175 \mathrm{p}$

RAO, D.N., MIKKELSEN, D.S. Effect of rice straw incorporation on rice plant growth and nutrition. Agronomy Journal, Madison, v.68, n.5, p.752-755, 1976.

SCOTT RUSSELL, R. Plant root systems: their function and interaction with the soil. New York: Mc Graw Hill Book Company limited, 1977. 298p.

WOJTCZAK, L. Effect of long-chain fatty acids and acyl-CoA on mitochondrial permeability, transport, and energy-coupling processes. Journal and Bionergetics of Biomenbranes, London, v.8, p.293-311, 1976.

Ciência Rural, v. 26, n. 1, 1996. 